\title{
The Social Life of Mortgage Delinquency and Default
}

\author{
Brian J. McCabe
}

Georgetown University

\begin{abstract}
Although falling behind on a mortgage loan has significant personal consequences, we know little about whether the experience of delinquency or default influences the housing market behavior of other people in the defaulter's social networks. In this article, I ask how exposure to mortgage default through social networks affects perceptions of the housing market, judgments about the strategic default behavior of other households, and expectations for homeownership. Although individuals purposively draw on information from their social networks to aid in their housing search, theories of social influence have yet to be applied to the negative experience of mortgage delinquency or default. Drawing on the National Housing Survey, I find that individuals exposed to mortgage strain through their social networks express more negative expectations for the housing market and hold more permissive attitudes about strategic default. Homeowners reporting network exposure to mortgage strain are more likely to prefer rental housing when they next move. These results are strongest when individuals are connected to someone who has fallen behind on a mortgage payment in the previous three months.
\end{abstract}

Keywords: housing; social networks; mortgage default; social influence; homeownership

Citation: McCabe, Brian J. 2018. "The Social Life of Mortgage Delinquency and Default." Sociological Science 5: 489-512.

Received: April 18, 2018

Accepted: May 26, 2018

Published: July 26, 2018

Editor(s): Jesper Sørensen, Sarah Soule

DOI: $10.15195 /$ v5.a21

Copyright: (C) 2018 The Author(s). This open-access article has been published under a Creative Commons Attribution License, which allows unrestricted use, distribution and reproduction, in any form, as long as the original author and source have been credited. (C) (i)
THE experience of mortgage strain is a deeply personal one. ${ }^{1}$ Falling behind on 1 mortgage payments or defaulting on a loan deepens financial hardship and leads to negative health outcomes, including increased stress and hospitalization (Alley et al. 2011; Keene, Cowan and Baker 2015). After a default, households are often forced to relocate, as lending institutions foreclose on their property. The resulting housing instability upends social connections, disrupts children's peer networks, and worsens the already precarious economic position of these households (Pribesh and Downey 1999; Been et al. 2011).

Although the personal consequences of mortgage strain are substantial, the impact of delinquency and default may not be limited exclusively to the household experiencing the event. If this information spreads across social ties, then the personal experience of mortgage strain could affect other individuals within a social network. Exposure to this event may impact how other people in the network evaluate the housing market or approach their own housing choices. Although theories of social influence have been used to explain many social behaviors, including peer effects in schools (Sacerdote 2001), the spread of political attitudes (Huckfeldt and Sprague 1995), and the contagion of various health behaviors (Cohen and Prinstein 2006), they have not previously been applied to the negative experience of mortgage strain. This omission is particularly noteworthy because individuals regularly rely on their social networks when making housing decisions. They purposively draw on others in their networks, including friends, realtors, and neighbors, to learn about community resources (e.g., schools) and gather information about local 
amenities when picking a neighborhood (Lareau and Goyette 2014; Weininger and Lareau 2014; Besbris 2016).

In this article, I test a series of hypotheses about the social influence of mortgage strain using data from the National Housing Survey. Specifically, I ask how exposure to mortgage default through social networks affects perceptions of the housing market, judgments about the strategic default behavior of other households, and expectations for homeownership. Bringing studies of social influence into the realm of the housing market, I consider two categories of influencing events: network ties to people who missed a mortgage payment in the previous three months and more distant social connections to people who experienced mortgage strain more than three months ago. By simultaneously investigating exposure to both recent and distant defaults, I evaluate whether temporal proximity to the experience of mortgage strain is associated with market expectations and attitudes.

The choice of the housing market as a site to study the influencing role of information shared across embedded networks is strategic. Increasingly, sociological studies of economic decision-making highlight the importance of social norms, networks, and conventions to understanding financial transactions, but their application to housing and home-buying decisions has gone largely unexplored (DiMaggio and Louch 1998; Besbris 2016). Instead, most research on the transition to homeownership (including where, whether, and when to buy a home) models the decision as a function of household characteristics or life-course attributes (Painter, Gabriel and Myers 2001; Gabriel and Stuart 2003; Hilber and Liu 2008). Building from these studies, my analysis contributes to a growing literature on the sociology of housing that considers home-buying behaviors (and other housing choices) within the social contexts in which they occur (Pattillo 2013; McCabe 2016; Zavisca and Gerber 2016; Manturuk, Lindblad, and Quercia 2017).

In this article, I begin by reviewing research on the personal consequences of mortgage delinquency and default. Although this research highlights the negative impact of mortgage strain on individual financial and health outcomes, it has little to say about the social influence of these events. Next, I introduce social network theories to explain how information spreads across social ties. Although there is ample evidence pointing to network effects on economic behavior, there has been no effort to understand whether the experience of mortgage strain spreads across network ties to influence others' housing market decisions. After briefly discussing the importance of social networks in the housing search, I use the National Housing Survey to test four hypotheses. In the findings section, I report that respondents who are exposed to mortgage strain through their social networks offer weaker assessments of the housing market and express more leniency toward the strategic default behaviors of other households. Homeowners who are exposed to mortgage strain are less likely to anticipate buying a home in the future. Although I cannot make strong causal claims from the observational data in the National Housing Survey, I note that my findings are consistent across model specifications. In conclusion, I contextualize these findings within broader research on social networks, economic decision-making, and the housing market. Although stigmatization around default behavior often keeps individuals from directly sharing their experiences within their social networks, I argue that this information still has a social life. 


\section{The Personal Impact of Mortgage Delinquency and Default}

Each year, a substantial number of American homeowners are delinquent on their monthly payments or default on their mortgage loan. In the run-up to the 2007 housing crisis, the expansion of exotic mortgage instruments, including interestonly loans and adjustable rate mortgages, combined with rising unemployment led to a sharp jump in mortgage delinquency. According to the Federal Reserve Bank of Chicago, nearly 5 percent of prime borrowers experienced default on their mortgage loan in 2007, which is nearly double the share from just two years earlier (Amromin and Paulson 2010). ${ }^{2}$ More than 20 percent of subprime borrowers were in default, although they accounted for a substantially smaller share of borrowers in the housing market (Amromin and Paulson 2010). In 2010, the delinquency rate for loans on single-family homes peaked above 11 percent before steadily declining to 4 percent by $2016 .^{3}$ Heightened rates of mortgage strain resulted in increased foreclosure rates across the United States, creating new social and economic challenges for households that had fallen behind on their mortgage payments.

Although mortgage strain is viewed primarily as an economic hardship, the personal experiences of delinquency and default extend beyond these financial challenges. When homeowners have trouble paying their mortgages or default on their loans, they often experience negative physical and mental health outcomes (Nettleton and Burrows 2000; Alley et al. 2011; Burgard, Seefeldt, and Zelner 2012; Cannuscio et al. 2012; Osypuk et al. 2012). Faced with increased stigmatization, mortgage default (and the resulting process of foreclosure) can result in depression and anxiety as households work to hide their mortgage strain from their social networks (Keene et al. 2015). Among elderly households experiencing mortgage delinquency, Alley et al. (2011) report declines in self-reported health behavior. Mortgage delinquency and foreclosure have also been linked to a spike in the suicide rate (Houle and Light 2014; Fowler et al. 2015). ${ }^{4}$

Social networks serve as an important resource for households navigating the experience of mortgage delinquency and default. In her ethnographic account of the mortgage modification experiences of Californian homeowners, Owens (2014) reveals that working-class homeowners are more likely to activate their social networks in order to find information to guide them through the mortgage modification process. Willing to share their experiences of default with people in their networks, these homeowners learn to avoid modification scams and temper their expectations for modification workouts. Notably, only by sharing their experiences within their networks are working-class homeowners able to find information that helps them through this process. By contrast, Owens (2014) reports that middle-class homeowners rarely share their experiences of mortgage strain, owing at least partly to feelings of shame or anxiety. By keeping their experiences private, middle-class homeowners rarely benefit from information shared through network ties about the modification process.

The reluctance of middle-class homeowners to share their experiences of mortgage strain reflects the continued stigmatization associated with mortgage delin- 
quency. Because buying a home remains a marker of social mobility and good citizenship for millions of households, losing that home to foreclosure brings a loss of social status (Dickerson 2014; McCabe 2016). Reflecting the social value of ownership, research on strategic default (the decision to intentionally default on a mortgage loan) points to the morally complex nature of housing transactions (White 2010). Although households that strategically default are often financially capable of making their monthly payments, they decide not to do so when the value of their outstanding mortgage loan is higher than the market value of their house. When households contemplate strategic default, they weigh their own ethical assessment of default alongside their future expectations of housing price appreciation (Seiler et al. 2012). Homeowners with weaker emotional attachment to their homes or a larger equity shortfall are more likely to contemplate strategic default (Guiso, Sapienza, and Zingales 2013).

\section{Information Exposure through Social Networks}

Personal information, like the experience of mortgage default, spreads across social connections as individuals share their own life events (or share information about others they know) with people in their networks. Information flows across social ties in several ways. Often, people purposively gather information from individuals they know to inform their own choices. They reach into their networks to learn about political candidates (Huckfeldt and Sprague 1995), select among consumer products (Brown and Reingen 1987), or locate service providers (Small 2009). Information is often shared selectively with certain people in a network through a process of selective disclosure, as in the case of abortion secrets (Cowan 2014) or political opinions (Cowan and Baldassari 2018). However, individuals may also unintentionally receive influential information through their social networks. Gossip and rumors spread unsolicited information from one person to another across network ties. Although online technologies have magnified and reshaped the contours of these networks, social learning and information sharing continue to occur through old-fashioned, person-to-person connections that center largely around geographic neighborhoods.

As information spreads through social networks, it influences individual attitudes and shapes personal behaviors. Across the social sciences but particularly in the discipline of sociology, studies of social influence identify countless examples of the way influential information shared across network ties impacts behaviors and attitudes. Sacerdote (2001) exploits the random assignment of college roommates to show peer effects in academic performance and participation in extracurricular groups, such as fraternities. Information spread across social networks influences smoking behavior (Christakis and Fowler 2008), adolescent health outcomes (Cohen and Prinstein 2006), suicidality (Bearman and Moody 2004), alcohol and drug use (Bauman and Ennett 1996), and personal happiness (Fowler and Christakis 2008). Together, this growing body of research confirms that many social phenomena are influenced by the information shared across network ties.

There are multiple mechanisms by which information spread through social networks influences social behaviors or attitudes. On one hand, networks simply 
expose people to influential information. Individuals gain access to resources that were previously unavailable to them as information migrates from one person to another. This type of exposure is critical to the work of social capital theorists, who point to the importance of network connections as a vehicle to gain advantages in the social world (Coleman 1988). These networks also reinforce specific norms and behaviors among in-group members. In networks composed of dense social ties, individuals may feel pressure to conform or "fit in" with the expectations of others in their networks. Information spread across social networks may also strengthen emotional or affective ties. Especially in homophilous social networks, in which individuals already share common personal traits and characteristics, information learned about others may deepen feelings of interconnectedness or create opportunities for social support (McPherson, Smith-Lovin, and Cook 2001). In the case of mortgage default, it may be homeowners (or specifically, homeowners with a mortgage) who are most influenced by information shared about others' default.

Although social networks can serve to spread information, reinforce in-group behavior, and generate emotional support, the power of these network connections often depends on the strength, density, and characteristics of the underlying dyadic ties (Latané 1981). In the case of mortgage strain, we may expect that geographically based social connections (for example, network ties to people living in the same community) serve as the primary conduit through which this information flows. Beyond the underlying strength or geographic proximity of social connections, the importance of information spread across network ties may depend on the timing of the influencing event. Information that was recently learned or connections to events that happened more recently may be more consequential for shaping social behaviors than events that occurred in the more distant past. Because individuals recall recent events when making decisions, the power of influential events may diminish over time.

\section{Housing, Networks, and Exposure to Mortgage Strain}

Individuals regularly utilize information from their social networks as they make decisions about their housing. When selecting a neighborhood to live in, they purposively draw on people they know to learn about local schools and gather information about community resources (Holme 2002; Lareau and Goyette 2014; Weininger and Lareau 2014). In interviews with both urban and suburban families, Weininger and Lareau (2014) show how social networks steer families in the process of neighborhood selection. Specifically, in choosing between multiple neighborhoods, people rely heavily on the experiences of others in their social networks rather than conducting other forms of research. They ask people they already trust to relay their experiences in communities and neighborhoods, using that information to guide their own housing choices.

Social networks are particularly important for low-income households making housing decisions in the Housing Choice Voucher (HCV) program. Voucher recipients often have more flexibility in selecting neighborhoods than other low-income households because their vouchers enable them to access a wider range of units. 
Still, these households lean heavily on their networks to decide where to move in a city, leading them to select communities where their friends and social contacts already live (Boyd 2008; Boyd et al. 2010; Kleit and Galvez 2011). For example, in a study of Seattle households displaced by redevelopment through the HOPE VI program, Kleit and Galvez (2011) report that information about neighborhoods gathered through network ties leads displaced families to move into high-poverty neighborhoods. Likewise, in a recent study of the residential decision-making process of immigrant families in the HCV program, Basolo and Nguyen (2009) report that immigrants rely heavily on friends and families in their housing search, leading them to neighborhoods with higher concentrations of immigrants. This reliance on network connections contributes to the reproduction of neighborhood inequality and reinforces patterns of residential segregation because low-income families select high-poverty neighborhoods populated by others within their social networks (Carrillo et al. 2016; Sharkey 2013; Owens and Clampet-Lundquist 2016; Krysan and Crowder 2017). Additionally, once low-income families select a neighborhood, they continue to gather information, find support, and learn about local resources from people within their existing networks, contributing to concerns about microsegregation within diverse neighborhoods (Gaumer, Jacobowitz, and Brooks-Gunn 2014; Tach 2014; Chaskin and Joseph 2015).

Although the research on housing and social networks primarily investigates the purposeful extraction of information in the neighborhood selection process, it tells us little about other types information flows within social networks that influence housing choices. Specifically, we know little about the way that information that has not been explicitly solicited but is still known to individuals shapes activities in the housing market. Although information gathered intentionally is a critical resource in the housing search, I hypothesize that other types of information learned through network interactions affect housing market expectations and behaviors.

To understand the social influence of mortgage strain, I outline four hypotheses. First, I consider whether knowledge of others' mortgage delinquency or default is associated with perceptions about the health or strength of the housing market, including expectations regarding the direction of housing prices. Households have many ways to gather information and make predictions about the market. They rely on the expertise of realtors (Besbris 2016) and lean on the experiences of friends and family (Laureau and Goyette 2014). Households may generalize from their personal experiences of buying (or renting) a home or rely on publicly available information about interest rates, housing starts, or sales prices. But just as households rely on their social networks to learn about schools and neighborhoods, they may also rely on these network ties to inform their understanding of the market. If so, then knowing about others' experiences of mortgage delinquency is likely to sour expectations for home prices and heighten concerns about market instability. As a result, I hypothesize first $\left(\mathrm{H}_{1}\right)$ that exposure to mortgage strain through social connections will be associated with more negative assessments of the state of the housing market.

Second, I evaluate whether exposure to mortgage strain is associated with more permissive attitudes about strategic default behaviors. In the wake of the housing crisis, millions of households were delinquent on their mortgage payments as they 
struggled financially. For underwater homeowners (those who owed more on their homes than those homes were worth), financial struggles often led them to consider strategically defaulting on their mortgage loans rather than continuing to pay off a loan that exceeded the value of their house. Recognizing that the way information shared across networks can deepen emotional and affective ties, social connections to the experience of mortgage delinquency may elicit greater sympathy toward the plight of struggling homeowners. Knowledge of others' financial struggles may lead individuals to recognize the serious financial challenges that lead to mortgage nonpayment. Therefore, I hypothesize second $\left(\mathrm{H}_{2}\right)$ that exposure to mortgage strain through social networks will be associated with more lenient judgments about the default behavior of underwater homeowners and those experiencing financial hardship.

Notably, the directionality of this claim is difficult to determine. It may be that exposure to default through social networks generates empathy for the situation of struggling homeowners. If so, then these network connections could help to humanize or personalize the experience of default, leading to more permissive attitudes. However, people who default on their mortgage payments may simply be more likely to selectively disclose their experiences to others who already hold permissive attitudes. Because the experience of mortgage default is often shared only selectively within a network (Owens 2014), defaulters may simply tell this "secret" to others who already hold a sympathetic position.

Finally, I consider whether exposure to mortgage strain through social networks is associated with expectations for future homeownership decisions. The preference for homeownership remains one of the most enduring commitments for most Americans (McCabe 2016). Nearly two-thirds of Americans own their own homes, and most renters expect to own a home at some point the future (Pew Research Center 2011). However, if households internalize the risks experienced by others in their social networks, then network exposure to mortgage default may reshape their own housing choices. Social proximity to defaulters could deepen risk aversion. Households may second guess the importance of homeownership when they hold close knowledge of others' mortgage default. This is likely to generate a more cautious approach to homeownership and temper expectations about the promise of buying a home. As a result, I hypothesize third $\left(\mathrm{H}_{3}\right)$ that exposure to mortgage strain through social networks will be associated with muted expectations about buying a home in the future.

Although these hypotheses offer general expectations about the social influence of mortgage delinquency, this influence may vary systematically by homeownership status. My fourth hypothesis $\left(\mathrm{H}_{4}\right)$ posits that across outcomes, homeowners will be more sensitive to network exposure to mortgage delinquency than renters. Because renters cannot experience default on a mortgage (as they do not, by definition, have a mortgage), their exposure to these negative experiences may be less influential in explaining their own preferences or behaviors in the housing market. 


\section{Data and Methods}

To test these hypotheses, I draw on multiple waves of the National Housing Survey (NHS). The NHS is a nationally representative, repeated cross-sectional survey of American adults conducted monthly since July 2010. Each wave of the NHS includes approximately 1,000 respondents. The survey asks respondents about a range of housing attitudes, beliefs, and behaviors, including questions about their preference for homeownership, their expectations about the housing market, and their experience of buying a home. To test the hypotheses outlined in the previous section, I draw on 30 consecutive, monthly cross-sections of the National Housing Survey between January 2011 and June 2013, several years after the collapse of the housing market. Despite the rich battery of items in the survey, the data set has rarely been used by sociologists (or other social scientists) to study the way Americans evaluate the market and make housing choices (Drew and Herbert 2013; McCabe 2018).

I use a series of questions from the National Housing Survey asking respondents about their expectations for the housing market, their attitudes toward the default behavior of others, and their own preferences for ownership. To test the first hypothesis, I utilize two questions about general expectations for the housing market. The first question reads, "In general, do you think this is a very good time to sell a house, a somewhat good time, a somewhat bad time, or a very bad time to sell a house?" I recode the measure into a dichotomous outcome identifying whether respondents believe it is a good (either very or somewhat) or bad (either very or somewhat) time to sell a house. This is an important indicator of the perceived health of the housing market because individuals are more likely to believe it is a good time to sell when they view the market to be strong. The second question asks, "During the next 12 months, do you think home prices in general will go up, go down, or stay the same as where they are now?" I recode the measure into a dichotomous outcome identifying whether respondents believe housing prices will go up or not (either stay the same or go down). By asking about expectations for housing prices, this item again captures perceptions about the state of the housing market. The measures are identified as "Good Time to Sell" and "Prices Will Go Up" in Table 1.

The second hypothesis concerns the permissiveness of attitudes toward homeowners struggling to make their mortgage payments. To test this hypothesis, I utilize two questions in the National Housing Survey. The first question asks, "If a person's home is now worth less than what they owe on it, do you think it's okay for them to stop paying their mortgage?" The second question asks, "If a person is facing financial distress, do you think it's okay for them to stop paying their mortgage?" In the tables, the measures are identified as "Default: Underwater" and "Default: Financial Distress." Both questions offer a dichotomous choice set measuring the permissiveness of attitudes toward default behaviors.

The final measure, which is used to test the third hypothesis, asks respondents about their own housing choices. It reads, "If you were going to move, would you be more likely to rent or buy?" Rather than capturing a broad assessment of the housing market, this measure captures personal plans for buying a home. It is 
Table 1: Housing market expectations and attitudes by homeownership status.

\begin{tabular}{lccc}
\hline & Total & Renter & Homeowner \\
\hline Good Time to Sell & 17.32 & 19.75 & 16.35 \\
Prices Will Go Up & 35.07 & 37.51 & 34.09 \\
Default: Underwater & 10.65 & 13.11 & 9.64 \\
Default: Financial Distress & 18.91 & 20.35 & 18.31 \\
Likely to Buy & 70.39 & 42.35 & 82.16 \\
\hline
\end{tabular}

Notes: This chart identifies the percentage of respondents who responded affirmatively to each statement in the National Housing Survey. Each of the differences between homeowners and renters is significant at the $p<0.01$ level.

recoded to identify whether respondents would be more likely to buy a home when they next move. It is labelled as "Likely to Buy" in the tables.

In Table 1, I report the responses to these five measures, including the responses for homeowners and renters separately. Respondents in the National Housing Survey were generally lukewarm about the housing market during the 30-month study period. On average, 17 percent of respondents reported that it was a good time to sell a home, and 35 percent of respondents expected prices to go up. Renters are slightly more optimistic than homeowners. However, responses to both questions changed substantially between January 2011 and June 2013. In Figure 1, I plot market expectations during the 30-month period of this study. Between January 2011 and June 2013, a growing share of Americans reported that it was a good time to sell a home as expectations for housing prices climbed.

Asked about default behavior, nearly 11 percent of respondents reported that it was acceptable for underwater homeowners to strategically default on their mortgage payments. Overall, 19 percent of respondents reported that it was acceptable for financially distressed homeowners to default. For both of these questions, renters hold slightly more permissive attitudes than homeowners, as reported in Table 1.

Finally, respondents in the National Housing Survey overwhelmingly expected to buy a home when they next moved. More than 70 percent of respondents said they were likely to buy a home compared to less than 30 percent who expected to rent one. Here, the differences by ownership status were stark. More than 82 percent of homeowners expected to move into a home that they own in the future compared to only 42 percent of renters.

To measure network exposure to mortgage strain, I draw on a series of questions from the National Housing Survey that asked respondents to identify the presence of people in their networks who experienced mortgage delinquency or default. Every respondent in the sample was asked, "Do you know of people in your area or neighborhood who have defaulted on their mortgage?" Respondents who answered yes (in other words, those who affirmatively reported that they knew of people who had defaulted on their mortgage) were then asked, "Do you know anyone who has stopped making their mortgage payments within the last three months?" Although the question wording is imprecise across items-the first asking whether respondents know of people and the second asking whether respondents know anyone- 


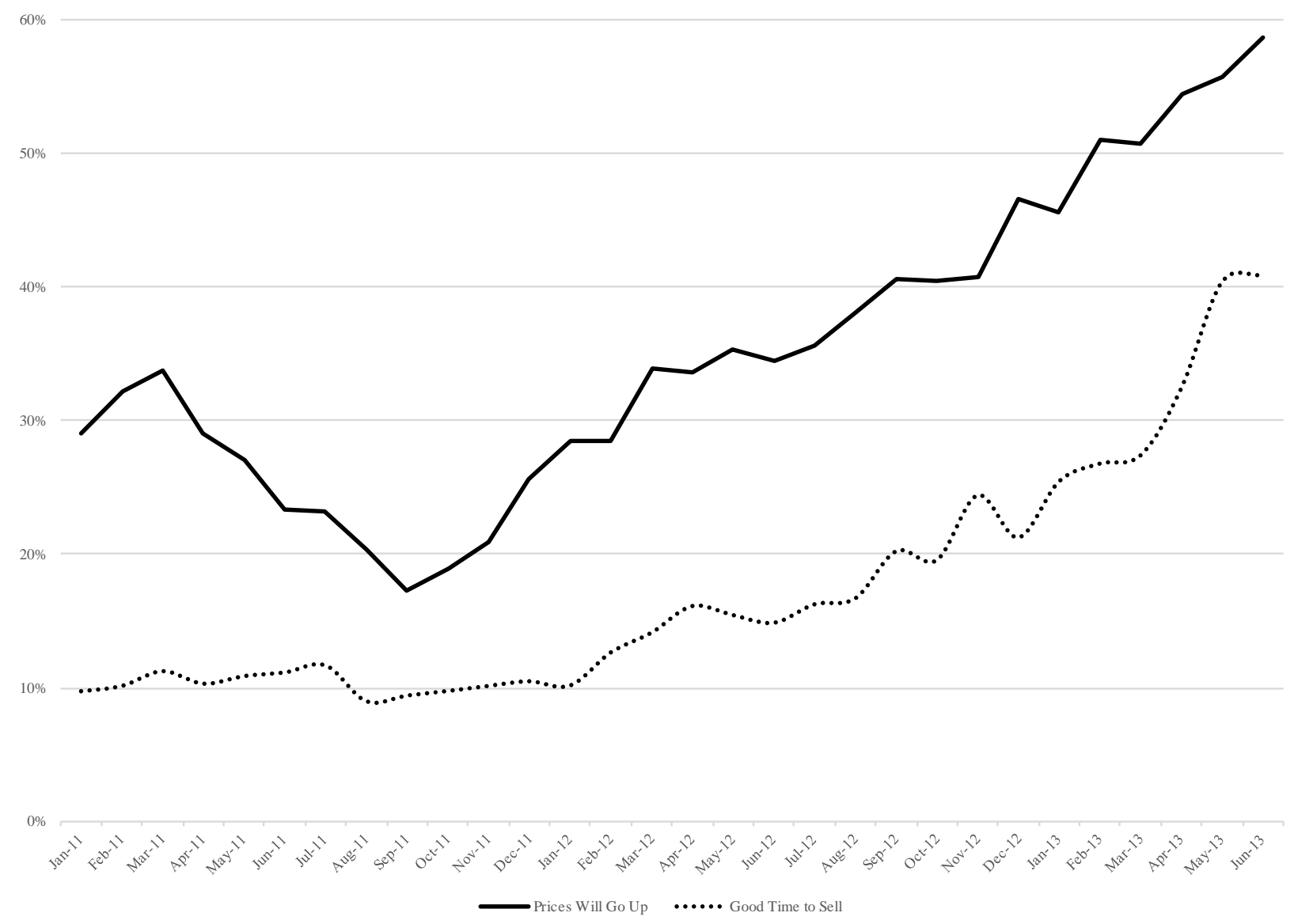

Figure 1: Housing market expectations, January 2011 to June 2013.

their sequential structure creates an opportunity to evaluate respondents' proximity to the experience of default through their social networks.

I use these two measures, whether respondents know of people who have defaulted in their neighborhoods and whether respondents know anyone who stopped paying their loans in the previous three months, to evaluate network exposure to mortgage strain. Combining these survey items, I construct a categorical variable identifying whether respondents have knowledge of mortgage delinquency within their social networks. Each respondent is classified into one of three mutually exclusive categories: they do not know of people who have defaulted on their mortgage loan; they know of people in their neighborhood who previously defaulted, but they do not know anyone who was delinquent in the past three months; or they know someone who was delinquent on their payments in the previous three months. Throughout the article, I refer to respondents who know of people in their neighborhood who defaulted on a mortgage loan but do not know anyone who did so in the previous three months as holding a distant connection to the experience of default. I refer to respondents who report knowing someone who stopped making 
their payments in the previous three months as holding a recent connection to the experience of default.

Twelve percent of respondents in the National Housing Survey reported that they know someone who has stopped paying their loan in the previous three months. Another 29 percent report knowing of people in their neighborhood who defaulted on their mortgage loans but not in the previous three months. Nearly 59 percent of respondents reported not knowing anyone who experienced mortgage strain. Although homeowners and renters appear to be equally likely to report exposure to the recent experience of default (12.0 percent of homeowners compared to 12.3 percent of renters), homeowners are about 7 percentage points more likely to report exposure to the distant experience of default. I report these descriptive statistics in Table A.1 of the online supplement.

In Table A.1, I also report descriptive statistics for the other variables in the analysis, including the basic demographic characteristics of survey respondents. In total, 54 percent of the sample is female, and 13 percent report being born outside of the United States. Respondents with a high school education comprise nearly 22 percent of the sample, and those with at least a college degree account for 46 percent of respondents. Almost two-thirds of respondents are white, and almost 13 percent are black. Nearly 71 percent of respondents own their own home (and about 45 percent of respondents hold a mortgage on the home they own). The remaining 29 percent of respondents rent their homes. I present these descriptive statistics separately for homeowners and renters in Table A.1.

Homeowners responded to an additional set of items about their housing market experiences. They were asked about the change in their home values since they bought their homes. The item read, "Thinking about the value of your home today compared to what you paid for the home, would you say your home is worth...," and it offered five categorical response options. The plurality of homeowners reported price appreciation greater than 20 percent since purchasing their homes. Overall, about 19 percent of homeowners reported that their home was worth less than they paid for it. Additionally, homeowners who reported holding a mortgage on their home were also asked about their experience of mortgage modification. The item read, "Have the terms of your mortgage, such as the rate, term, payment, or principal, ever been modified because you were behind on or defaulted on your mortgage?" Although this measure may not capture all forms of mortgage delinquency, it does offer a partial coverage for households who experience mortgage modification. During the study period, only 6 percent of homeowners holding a mortgage reported personal experiences with mortgage modification.

The analysis begins with a sample of 29,084 respondents in the National Housing Survey from January 2011 to June 2013. I select this range of dates because the items about network exposure were only included in these waves. This period represents a unique moment in the American housing market when confidence in the market was beginning to rebound from the crisis several years earlier (as shown in Figure 1). For variables in Table A.1 with missing data, I create a categorical indicator to identify observations with missing values. ${ }^{5}$ Doing so allows me to utilize the full set of cases in the National Housing Survey without losing respondents to listwise 
deletion. Still, the number of respondents in the sample varies slightly across outcomes because of missing values on the dependent variables.

For each outcome in Table 1, I estimate a series of logistic regressions focusing on whether respondents report exposure through their social networks to either a recent or distant experience of mortgage strain. Each model controls for the month the survey was fielded to account for changing housing market conditions during the 30-month period of the study. I use the sample weights provided in the National Housing Survey. In the first set of models, I control for the demographic characteristics listed in Table A.1, including educational attainment, gender, income, age, and homeownership status, to isolate network exposure to default. In the second set of models, I add an interaction term to test for heterogeneity in the effect of network exposure by homeownership status $\left(\mathrm{H}_{4}\right)$. Because theories of social influence suggest that influencing events may be more consequential for individuals who share common traits, we may expect larger effects of exposure among homeowners. In the third set of models, I limit the sample to homeowners who hold a mortgage in order to account for the personal experience of mortgage modification and price appreciation. Because the item on mortgage modification was asked only during a 17-month period between February 2012 to June 2013, the initial sample size for these models restricted only to homeowners with a mortgage is reduced to 7,435 observations.

The primary methodological challenge in identifying the causal effect of network exposure to mortgage default is untangling social networks effects from the effects of neighborhood-level housing markets. People living in neighborhoods with depressed housing markets, or places with a higher incidence of default, may be more likely to report network exposure to mortgage default simply because the incidence is higher. As a result, any observed relationship between network exposure and negative assessments of the housing market could be driven by neighborhood-level housing markets. To test whether the observed associations are spuriously driven by neighborhood characteristics, I report an additional set of models in Table A.3 in the online supplement that includes several zip code-level covariates. Specifically, I control for the homeownership rate from the 2010 census and the median neighborhood income from the 2011 American Community Survey. Additionally, I include two variables from the realty website Zillow.com to account for housing market conditions: the median estimated home value for all homes in a zip code and the percent of homes that decreased in value in the previous year. ${ }^{6}$ Survey respondents in the National Housing Survey are matched to zip code-level Zillow data in the month the survey was fielded (i.e., a respondent who completed the NHS in January 2012 is matched with Zillow's housing market data for January 2012).

\section{Results}

Findings from the National Housing Survey reveal a consistent association between exposure to mortgage strain and housing market expectations and attitudes. Individuals with network ties to people who have been delinquent on their loan payments are more likely to report negative expectations for the housing market. They 
also express more permissive attitudes toward strategic default. Homeowners with a recent connection to mortgage strain are less likely to anticipate owning a home in the future. Although the observational nature of the data limits the possibility for strong causal interpretation, the patterns are consistent across model specifications, including the models accounting for the housing market experiences of mortgaged homeowners. In the tables, I report only the coefficients of the variables related to homeownership and network exposure, although the models are estimated by using the full set of demographic covariates from Table A.1. The complete regression output is reported in the online supplement in Table A.2. Regression models with neighborhood-level measures, which confirm that the main findings are robust to the inclusion of neighborhood-level demographic and housing market variables, are reported in the online supplement in Table A.3.

\section{Housing Market Expectations}

The first set of regressions, reported in Table 2, examines expectations for the housing market by investigating whether respondents believe housing prices will increase and whether they agree that it is a good time to sell a home. For both measures, respondents who were exposed to mortgage default through their social networks express substantially more negative views of the housing market. Asked whether it was a good time to sell a home, respondents with connections to both recent and distant experiences of mortgage default were less likely to believe that it is a good time to sell (Table 2, column 1). These effects do not vary by homeownership status (Table 2, column 2).

The findings are robust to the inclusion of two measures identifying housing market experiences of mortgaged homeowners. Homeowners who experienced positive price appreciation are substantially more optimistic about the current state of the market, whereas those who experienced negative price growth are more pessimistic. The personal experience of mortgage modification is not associated with expectations about the housing market (Table 2, columns 3). Even after limiting the sample to mortgaged homeowners and accounting for their own market experiences, recent exposure to mortgage default is strongly associated with housing market expectations.

Respondents with network ties to a recent mortgage default are also more pessimistic about future housing prices. They are less likely to believe that home values will rise (Table 2, column 4). However, the effect of a distant connection is not statistically significant. Although this finding confirms the significance of short-term exposure to mortgage default, it suggests that the influence of network exposure dissipates over time. In assessing housing price growth, respondents appear to be sensitive to the recent experience of mortgage default, but they are insensitive to defaults that occurred in the more distant past. When I evaluate heterogeneity between homeowners and renters, the coefficient for recent exposure to mortgage default loses its significance, and I find no evidence of variation by homeownership status (Table 2, column 5). The coefficient associated with a recent exposure to default is not significant when the model is limited to homeowners with a mortgage (Table 2, column 6). 
Table 2: Odds ratios from logistic regression of housing market expectations.

\begin{tabular}{|c|c|c|c|c|c|c|}
\hline & \multicolumn{3}{|c|}{$\begin{array}{l}\text { Good Time } \\
\text { to Sell }\end{array}$} & \multicolumn{3}{|c|}{$\begin{array}{l}\text { Prices Will } \\
\text { Go Up }\end{array}$} \\
\hline & (1) & $(2)$ & (3) & (4) & (5) & (6) \\
\hline Default: Distant Connection & $\begin{array}{r}0.736^{\dagger} \\
(0.037)\end{array}$ & $\begin{array}{c}0.712^{\dagger} \\
(0.070)\end{array}$ & $\begin{array}{c}0.874 \\
(0.072)\end{array}$ & $\begin{array}{c}1.003 \\
(0.039)\end{array}$ & $\begin{array}{c}0.968 \\
(0.077)\end{array}$ & $\begin{array}{c}0.981 \\
(0.066)\end{array}$ \\
\hline Default: Recent Connection & $\begin{array}{r}0.628^{\dagger} \\
(0.049)\end{array}$ & $\begin{array}{r}0.677^{+} \\
(0.097)\end{array}$ & $\begin{array}{r}0.663^{\dagger} \\
(0.093)\end{array}$ & $\begin{array}{c}0.881^{*} \\
(0.049)\end{array}$ & $\begin{array}{c}0.876 \\
(0.093)\end{array}$ & $\begin{array}{c}0.856 \\
(0.090)\end{array}$ \\
\hline Homeowner & $\begin{array}{c}0.915 \\
(0.052)\end{array}$ & $\begin{array}{c}0.916 \\
(0.061)\end{array}$ & & $\begin{array}{c}0.881^{+} \\
(0.039)\end{array}$ & $\begin{array}{c}0.868^{\dagger} \\
(0.046)\end{array}$ & \\
\hline Distant Connection * Homeowner & & $\begin{array}{l}1.050 \\
(0.119)\end{array}$ & & & & $\begin{array}{c}1.054 \\
(0.095)\end{array}$ \\
\hline Recent Connection * Homeowner & & $\begin{array}{c}0.887 \\
(0.149)\end{array}$ & & & & $\begin{array}{c}1.009 \\
(0.124)\end{array}$ \\
\hline Current Home Value: Increase $20 \%$ or More & & & $\begin{array}{r}1.495^{\dagger} \\
(0.159)\end{array}$ & & & $\begin{array}{c}1.135 \\
(0.099)\end{array}$ \\
\hline Current Home Value: Increase 5\%-20\% & & & $\begin{array}{r}1.536^{\dagger} \\
(0.176)\end{array}$ & & & $\begin{array}{c}1.153 \\
(0.111)\end{array}$ \\
\hline Current Home Value: Decrease 5\%-20\% & & & $\begin{array}{r}0.506^{\dagger} \\
(0.077)\end{array}$ & & & $\begin{array}{l}1.046 \\
(0.116)\end{array}$ \\
\hline Current Home Value: Decrease $20 \%$ or More & & & $\begin{array}{r}0.550^{+} \\
(0.093)\end{array}$ & & & $\begin{array}{c}0.967 \\
(0.124)\end{array}$ \\
\hline Mortgage Modification & & & $\begin{array}{c}0.947 \\
(0.172)\end{array}$ & & & $\begin{array}{l}1.031 \\
(0.144)\end{array}$ \\
\hline Constant & $\begin{array}{c}0.149^{\dagger} \\
(0.030)\end{array}$ & $\begin{array}{c}0.149^{\dagger} \\
(0.031)\end{array}$ & $\begin{array}{r}0.081^{+} \\
(0.029)\end{array}$ & $\begin{array}{r}0.533^{+} \\
(0.072)\end{array}$ & $\begin{array}{r}0.538^{+} \\
(0.073)\end{array}$ & $\begin{array}{r}0.245^{+} \\
(0.069)\end{array}$ \\
\hline Observations & 28,103 & 28,103 & 7,267 & 27,941 & 27,941 & 7,212 \\
\hline Pseudo $R^{2}$ & 0.071 & 0.071 & 0.099 & 0.051 & 0.051 & 0.054 \\
\hline
\end{tabular}

Notes: Each regression model includes the full set of demographic covariates reported in Table A.1 of the online supplement. The models also account for the month in which the survey was fielded. The table reports the exponentiated coefficients with the standard errors in parentheses.

${ }^{*} p<0.05,{ }^{\dagger} p<0.01$

To visually display these differences, I graph the findings from Table 2, columns 1 and 4, in Figure 2. The bars report the predicted probabilities that three categories of respondents (those without a connection to mortgage default, those with a distant network exposure to mortgage default, and those with a recent network exposure to mortgage default) will respond affirmatively to the statements about housing prices and the timing of home sales (holding other measures in the model at their modal values).

\section{Attitudes about Strategic Default}

In Table 3, I consider whether individuals who report network exposure to mortgage default express more permissive attitudes toward the strategic default behavior of underwater homeowners or homeowners experiencing financial hardship. Compared to those without defaulters in their social networks, respondents who report 
0.35

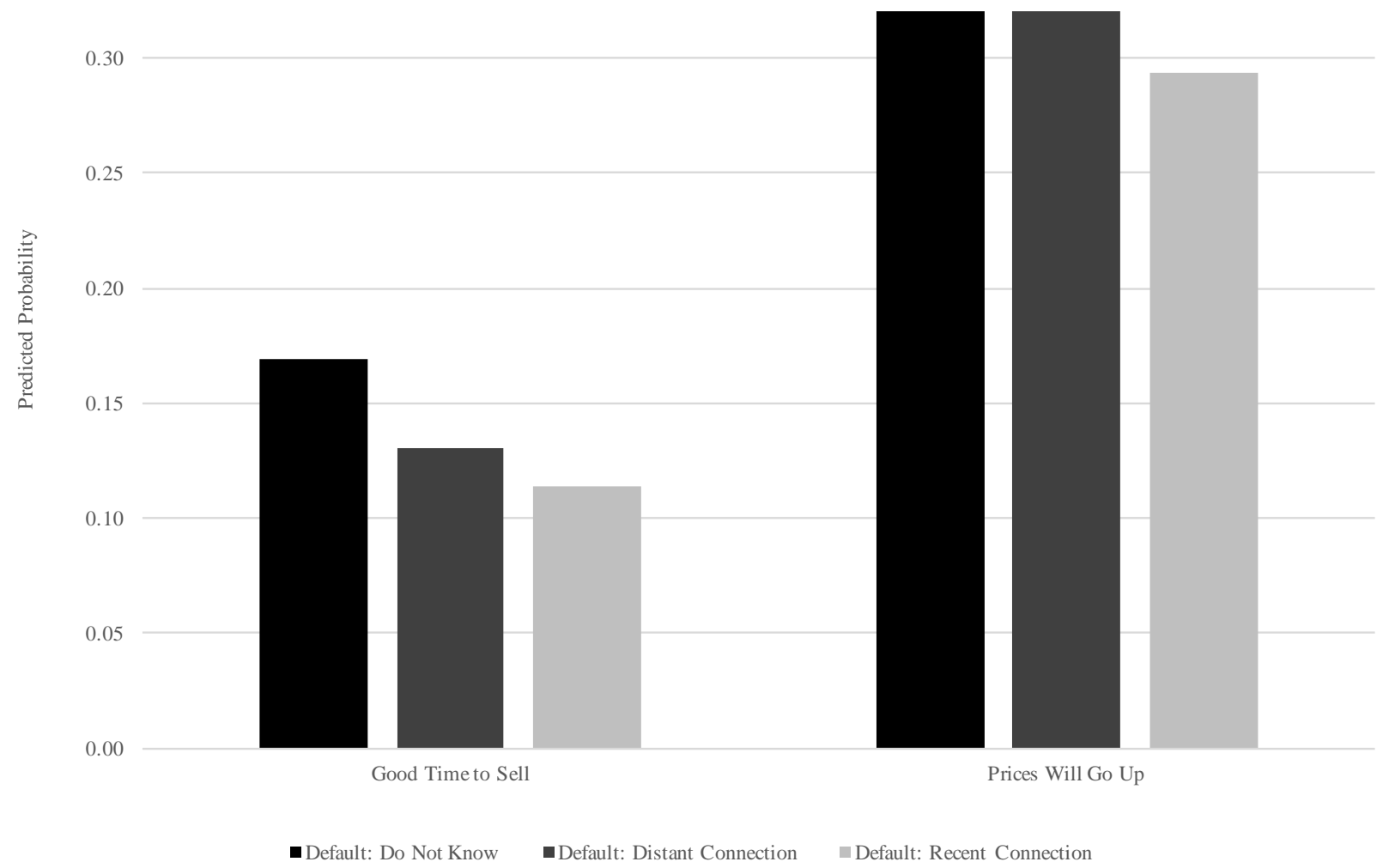

Figure 2: Predicted probabilities for housing market expectations by exposure to mortgage default. Notes: The predicted probabilities are estimated by holding each of the variables in the model at their modal value. They are reported for a nonimmigrant, white, female respondent living in an urban area. She is between 45 and 59 years old, has some college education, and reports an income between $\$ 25,000$ and $\$ 50,000$. The respondent has no children and owns a home.

a distant connection to mortgage strain are 13 percent more likely to express permissive attitudes about underwater homeowners contemplating default. Those reporting network exposure to a recent default experience are 64 percent more likely to report that it is acceptable for underwater homeowners to default on their mortgage payments (Table 3, column 1). These findings suggest that network exposure to homeowners experiencing mortgage strain, and especially to homeowners who recently defaulted, is associated with more permissive social attitudes. Although homeowners are generally less lenient than renters, there is no evidence that this effect varies by homeownership status (Table 3, column 2).

I report similar findings when I evaluate attitudes about the default behavior of households experiencing financial hardship. Respondents are 23 percent more likely to report permissive attitudes about homeowners in financial hardship when they hold a distant connection to mortgage strain. Compared to individuals who have not been exposed to default through their social networks, those with knowledge of a recent mortgage default are 61 percent more likely to express permissive attitudes 
Table 3: Odds ratios from logistic regression of attitudes towards default.

\begin{tabular}{|c|c|c|c|c|c|c|}
\hline & \multicolumn{3}{|c|}{$\begin{array}{c}\text { Default: } \\
\text { Underwater }\end{array}$} & \multicolumn{3}{|c|}{$\begin{array}{c}\text { Default: } \\
\text { Financial Distress }\end{array}$} \\
\hline & (1) & $(2)$ & (3) & (4) & (5) & (6) \\
\hline \multirow[t]{2}{*}{ Default: Distant Connection } & $1.132 *$ & 1.235 & 0.955 & $1.227^{\dagger}$ & $1.351^{\dagger}$ & 1.003 \\
\hline & $(0.071)$ & $(0.140)$ & $(0.115)$ & $(0.057)$ & $(0.126)$ & $(0.087)$ \\
\hline \multirow[t]{2}{*}{ Default: Recent Connection } & $1.644^{+}$ & $1.559^{+}$ & $1.710^{+}$ & $1.612^{+}$ & $1.492^{+}$ & $1.420^{\dagger}$ \\
\hline & $(0.123)$ & $(0.202)$ & $(0.250)$ & $(0.098)$ & $(0.163)$ & $(0.166)$ \\
\hline \multirow[t]{2}{*}{ Homeowner } & $0.744^{+}$ & $0.761^{+}$ & & $0.857^{+}$ & $0.875^{*}$ & \\
\hline & $(0.050)$ & $(0.063)$ & & $(0.045)$ & $(0.057)$ & \\
\hline \multirow[t]{2}{*}{ Distant Connection * Homeowner } & & 0.868 & & & 0.868 & \\
\hline & & $(0.115)$ & & & $(0.092)$ & \\
\hline \multirow[t]{2}{*}{ Recent Connection * Homeowner } & & 1.087 & & & 1.121 & \\
\hline & & $(0.169)$ & & & $(0.145)$ & \\
\hline \multirow[t]{2}{*}{ Current Home Value: Increase $20 \%$ or More } & & & 1.036 & & & 0.809 \\
\hline & & & $(0.156)$ & & & $(0.091)$ \\
\hline \multirow[t]{2}{*}{ Current Home Value: Increase 5\%-20\% } & & & 1.051 & & & $0.779 *$ \\
\hline & & & $(0.174)$ & & & $(0.098)$ \\
\hline \multirow[t]{2}{*}{ Current Home Value: Decrease 5\%-20\% } & & & 0.704 & & & 1.001 \\
\hline & & & $(0.145)$ & & & $(0.137)$ \\
\hline \multirow[t]{2}{*}{ Current Home Value: Decrease $20 \%$ or More } & & & 1.382 & & & $1.525^{\dagger}$ \\
\hline & & & $(0.259)$ & & & $(0.210)$ \\
\hline \multirow[t]{2}{*}{ Mortgage Modification } & & & $2.233^{+}$ & & & $2.160^{\dagger}$ \\
\hline & & & $(0.419)$ & & & $(0.308)$ \\
\hline \multirow[t]{2}{*}{ Constant } & $0.150^{\dagger}$ & $0.148^{+}$ & $0.119^{\dagger}$ & $0.226^{+}$ & $0.222^{\dagger}$ & $0.147^{\dagger}$ \\
\hline & $(0.031)$ & $(0.031)$ & $(0.051)$ & $(0.035)$ & $(0.035)$ & $(0.046)$ \\
\hline Observations & 27,989 & 27,989 & 7,234 & 27,630 & 27,630 & 7,123 \\
\hline Pseudo $R^{2}$ & 0.051 & 0.051 & 0.082 & 0.018 & 0.018 & 0.042 \\
\hline
\end{tabular}

Notes: Each regression model includes the full set of demographic covariates reported in Table A.1 of the online supplement. The models also account for the month in which the survey was fielded. The table reports the exponentiated coefficients with the standard errors in parentheses.

${ }^{*} p<0.05,{ }^{\dagger} p<0.01$

about homeowners who stop paying their mortgage loans when they experience financial distress (Table 3, column 4). Again, the importance of network exposure does not vary systematically by homeownership status (Table 3, columns 5). In Figure 3, I graph the predicted probabilities from Table 3, columns 1 and 4.

These findings for recent exposure to mortgage strain are robust to the inclusion of personal housing market experiences in the subsample of mortgaged homeowners. Homeowners who have undergone a mortgage modification are more than twice as likely to report permissive attitudes when asked about strategic default behaviors. Likewise, homeowners who themselves experienced strong, negative price appreciation in the housing market are substantially more likely to express permissive attitudes when asked about the default behavior of other homeowners experiencing financial distress. Even after accounting for their personal experiences in the housing market, mortgaged homeowners who report network exposure 
0.25

0.20

0.15

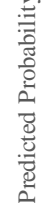

0.10

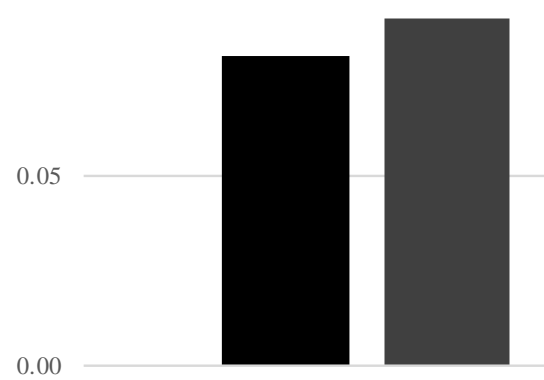

Default: Underwater

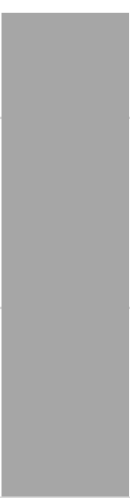

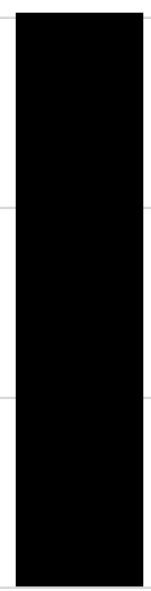

Default: Financial Distress

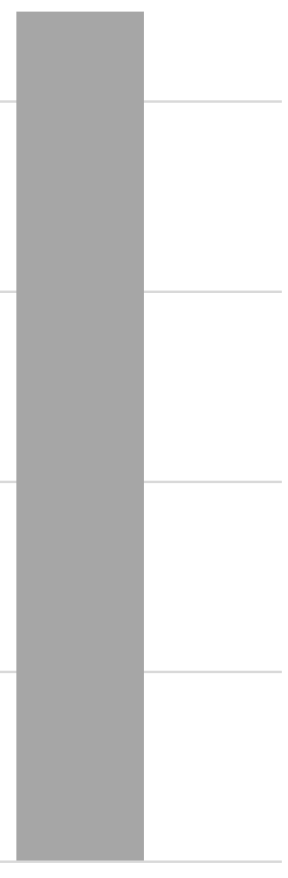

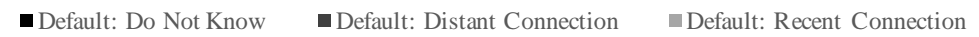

Figure 3: Predicted probabilities for attitudes toward default behavior by exposure to mortgage default. Notes: The predicted probabilities are estimated by holding each of the variables in the model at their modal value. They are reported for a nonimmigrant, white, female respondent living in an urban area. She is between 45 and 59 years old, has some college education, and reports an income between $\$ 25,000$ and $\$ 50,000$. The respondent has no children and owns a home.

to a recent experience of mortgage strain are substantially more likely to express permissive attitudes (Table 3, columns 3 and 6).

\section{Future Homeownership Plans}

In Table 4, I report that network exposure to mortgage default is not a significant predictor of future home-buying plans for the full sample of respondents (Table 4, column 1). However, these null findings mask heterogeneity between homeowners and renters in the way that network exposure shapes expectations for homeownership. Renters with a social connection to default appear slightly more likely to anticipate buying a home when they next move compared to those without network exposure to default, a finding that suggests that renters may see an opportunity to enter the housing market when they are exposed to the experience of mortgage strain. And although homeowners remain substantially more likely than renters to anticipate buying a home when they next move, the significant coefficients on the 
Table 4: Odds ratios from logistic regression of expected homeownership decisions.

\begin{tabular}{|c|c|c|c|}
\hline & & ikely Bu & \\
\hline & (1) & (2) & (3) \\
\hline Default: Distant Connection & $\begin{array}{c}1.066 \\
(0.049)\end{array}$ & $\begin{array}{c}1.180^{*} \\
(0.091)\end{array}$ & $\begin{array}{c}0.921 \\
(0.090)\end{array}$ \\
\hline Default: Recent Connection & $\begin{array}{c}0.996 \\
(0.064)\end{array}$ & $\begin{array}{c}1.264^{*} \\
(0.124)\end{array}$ & $\begin{array}{r}0.733^{*} \\
(0.100)\end{array}$ \\
\hline Homeowner & $\begin{array}{r}5.095^{+} \\
(0.244)\end{array}$ & $\begin{array}{c}5.688^{\dagger} \\
(0.335)\end{array}$ & \\
\hline Distant Connection * Homeowner & & $\begin{array}{c}0.829^{*} \\
(0.079)\end{array}$ & \\
\hline Recent Connection * Homeowner & & $\begin{array}{c}0.641^{\dagger} \\
(0.079)\end{array}$ & \\
\hline Current Home Value: Increase $20 \%$ or More & & & $\begin{array}{c}1.143 \\
(0.148)\end{array}$ \\
\hline Current Home Value: Increase 5\%-20\% & & & $\begin{array}{c}1.033 \\
(0.151)\end{array}$ \\
\hline Current Home Value: Decrease 5\%-20\% & & & $\begin{array}{c}0.856 \\
(0.131)\end{array}$ \\
\hline Current Home Value: Decrease $20 \%$ or More & & & $\begin{array}{r}0.550^{+} \\
(0.085)\end{array}$ \\
\hline Mortgage Modification & & & $\begin{array}{r}0.559^{\dagger} \\
(0.084)\end{array}$ \\
\hline Constant & $\begin{array}{r}0.435^{+} \\
(0.065)\end{array}$ & $\begin{array}{c}0.418^{+} \\
(0.064)\end{array}$ & $\begin{array}{r}3.330^{+} \\
(1.114)\end{array}$ \\
\hline Observations & 27,727 & 27,727 & 7,157 \\
\hline Pseudo $R^{2}$ & 0.186 & 0.187 & 0.095 \\
\hline
\end{tabular}

Notes: Each regression model includes the full set of demographic covariates reported in Table A.1 of the online supplement. The models also account for the month in which the survey was fielded. The table reports the exponentiated coefficients with the standard errors in parentheses.

${ }^{*} p<0.05,{ }^{\dagger} p<0.01$

interaction term suggest that homeowners exposed to mortgage delinquency are less likely to prefer homeownership compared to homeowners without network exposure (Table 4, column 2).

This negative association among homeowners is robust to the inclusion of their own housing market experiences. As expected, negative experiences in the housing market, including strong negative price appreciation and the personal experience of mortgage modification, moderate expectations about buying a home by decreasing the likelihood that homeowners expect to buy a home when they next move (Table 4, column 3). Still, even after accounting for their own experiences in the housing market, mortgaged homeowners with a network tie to a recent experience of mortgage strain are substantially less likely to anticipate buying a home in the future. 


\section{Discussion and Conclusion}

In this article, I present evidence about the relationship between network exposure to mortgage strain and perceptions about the housing market. Although previous studies highlight the positive role of network ties in the purposive gathering of housing information from realtors, friends, and neighbors, there has been little effort to understand how network exposure to others' negative housing market experiences shapes the way that people view their own housing situation. This omission is noteworthy because millions of Americans know people who have experienced mortgage strain. In fact, according to the National Housing Survey, more than 40 percent of Americans know of someone in their community who has fallen behind on their mortgage payments. Between 2011 and 2013, when the data for this article were collected, about one in eight Americans reported knowing someone who had experienced mortgage delinquency in the previous three months.

My analysis confirms that exposure to mortgage default through social networks influences the way individuals approach the housing market. Network exposure to mortgage strain (and specifically, exposure to an event within the last three months) leads individuals to report more negative expectations for the housing market and more lenient attitudes toward struggling homeowners. Homeowners who were exposed to mortgage strain through their networks report that they are less likely to buy a home when they next move. These findings confirm that the experience of mortgage default reaches beyond the individual experiencing the negative event. Although stigmatization often keeps people from sharing their experiences of mortgage strain or leads them to disclose it only selectively to people in their networks, mortgage delinquency has a social life that has gone largely unrecognized.

Although the National Housing Survey offers an important first look into the social influence of mortgage delinquency, the data have several limitations. Although I am able to distinguish between recent and distant exposure to mortgage strain, the structure of the data does not allow me to consider the intensity (or strength) of social connectedness. Although respondents were asked whether they knew someone who defaulted on their mortgage, they were not asked how many people they knew. To the extent that these effects are cumulative, the social impact of default should be stronger as people report more network ties to individuals who defaulted. Similarly, the survey cannot be used to evaluate the strength of those embedded ties. Network exposure to the default experience of a close friend or family member is likely to be more influential than the default experience of a more distant neighbor even though the respondents knows both of those people.

Finally, although the survey distinguishes events that occurred in the previous three months from those that occurred more than three months ago, a more finegrained measure of timing would enable me to identify clearer temporal patterns. Knowledge of a recent default was strongly associated with expectations for the housing market, a finding that is consistent across outcomes in the article. However, exposure to an event that occurred more than three months before the survey was fielded exhibited a notably weaker influence. These results suggest that mortgage strain has strong and immediate influence on others' attitudes and expectations, 
but its importance dissipates over time. Although the impact of network exposure declines as individuals gain distance from the event, the data are ill suited for a more nuanced investigation of the half-life of mortgage strain.

Despite these limitations, this article highlights the importance of thinking about mortgage strain as a socially influential event rather than one that affects only the household experiencing the delinquency. Each year, millions of Americans are exposed to the experience of mortgage strain through their friends and neighbors. As this information makes its way through social networks, it affects the way people think about the housing market and their own homeownership decisions.

\section{Notes}

1 Although the terminology of mortgage strain is sometimes used to describe cost-burdened homeowners paying more than 30 percent of their income toward their mortgage costs, I use the term as shorthand for the experience of mortgage delinquency and default (Keene et al. 2015).

2 The Federal Reserve Bank of Chicago defines a default as a borrower who is 60 days or more overdue on a payment 12 months after being issued the loan.

3 See "Delinquency Rate on Single-Family Residential Mortgages." Federal Reserve Bank of St. Louis. https://fred.stlouisfed.org/series/DRSFRMACBS.

4 Although the experience of mortgage strain leads to negative health outcomes, poor health conditions may also increase the likelihood of mortgage default (Houle and Keene 2015).

5 The initial sample for this 30-month period is 30,061 respondents. However, I exclude 977 respondents with missing data on the key variable identifying network exposure to the experience of mortgage default. More than 84 percent of respondents report no missing data on the variables in Table A.1. About 12 percent are missing data on only one variable. The remaining 4 percent of observations are missing data on at least two variables in the analysis.

6 Whereas the census data provide full coverage of zip codes, the Zillow data provide incomplete coverage of zip codes. For additional information on the data collected and reported by Zillow, visit https://www.zillow.com/research/data/.

\section{References}

Alley, Dawn E., Jennifer Lloyd, José A. Pagán, Craig E. Pollack, Michelle Shardell, and Carolyn Cannuscio. 2011. "Mortgage Delinquency and Changes in Access to Health Resources and Depressive Symptoms in a Nationally Representative Cohort of Americans Older Than 50 Years." American Journal of Public Health 101:2293-8. https : //doi . org/10. 2105/AJPH. 2011.300245.

Amromin, Gene, and Anna L. Paulson. 2010. "Default Rates on Prime and Subprime Mortgages: Differences and Similarities." Federal Reserve Bank of Chicago. https://www. chicagofed.org/publications/profitwise-news-and-views/2010/ pnv-september 2010 .

Basolo, Victoria, and Mai Thi Nguyen. 2009. "Immigrants' Housing Search and Neighborhood Conditions: A Comparative Analysis of Housing Choice Voucher Holders." Cityscape 11:99-126. 
Bauman, Karl E., and Susan T. Ennett. 1996. "On the Importance of Peer Influence for Adolescent Drug Use: Commonly Neglected Considerations." Addiction 91:185-98.

Bearman, Peter S., and James Moody. 2004. "Suicide and Friendships Among American Adolescents." American Journal of Public Health 94:89-95. https://doi .org/10.2105/ AJPH.94.1.89.

Been, Vicki, Ingrid Gould Ellen, Amy Ellen Schwartz, Leanna Stiefel, and Meryle Weinstein. 2011. “Does Losing Your Home Mean Losing Your School?: Effects of Foreclosures on the School Mobility of Children." Regional Science and Urban Economics 41:407-14. https://doi.org/10.1016/j.regsciurbeco.2011.02.006.

Besbris, Max. 2016. "Romancing the Home: Emotions and the Interactional Creation of Demand in the Housing Market." Socio-Economic Review 14:461-82. https ://doi .org/ 10.1093/ser/mww004.

Boyd, Melody L. 2008. "The Role of Social Networks in Making Housing Choices: The Experience of the Gautreaux Two Residential Mobility Program." Cityscape 10:41-63.

Boyd, Melody L., Kathryn Edin, Susan Clampet-Lundquist, and Greg J. Duncan. 2010. “The Durability of Gains from the Gautreaux Two Residential Mobility Program: A Qualitative Analysis of Who Stays and Who Moves from Low-Poverty Neighborhoods." Housing Policy Debate 20:119-46. https: //doi .org/10.1080/10511481003599902.

Brown, Jacqueline Johnson, and Peter H. Reingen. 1987. "Social Ties and Word-of-Mouth Referral Behavior." Journal of Consumer Research 14:350-62. https : //doi .org/10 . 1086/ 209118.

Burgard, Sarah A., Kristin S. Seefeldt, and Sarah Zelner. 2012. "Housing Instability and Health: Findings from the Michigan Recession and Recovery Study." Social Science and Medicine 75:2215-24. https://doi .org/10.1016/j . socscimed.2012.08.020.

Cannuscio, Carolyn C., Dawn E. Alley, José A. Pagán, Beth Soldo, Sarah Krasny, Michelle Shardell, David A. Asch, and Terri H. Lipman. 2012. "Housing Strain, Mortgage Foreclosure, and Health." Nursing Outlook 60:134-42. https://doi.org/10.1016/j . outlook. 2011.08 .004$.

Carrillo, Laura, Mary Pattillo, Erin Hardy, and Dolores Acevedo-Garcia. 2016. “Housing Decisions Among Low-Income Hispanic Households in Chicago." Cityscape 18:109-49.

Chaskin, Robert J., and Mark L. Joseph. 2015. Integrating the Inner City: The Promise and Perils of Mixed-Income Public Housing Transformation. Chicago, IL: University of Chicago Press. https://doi.org/10.7208/chicago/9780226303901.001.0001.

Christakis, Nicholas A., and James A. Fowler. 2008. "The Collective Dynamics of Smoking in a Large Social Network." New England Journal of Medicine 358:2249-58. https : //doi . org/10.1056/NEJMsa0706154.

Cohen, Geoffrey L., and Mitchell J. Prinstein. 2006. “Peer Contagion of Aggression and Health Risk Behavior Among Adolescent Males: An Experimental Investigation of Effects on Public Conduct and Private Attitudes." Child Development 77:967-83. https : //doi.org/10.1111/j.1467-8624.2006.00913.x.

Coleman, James. 1988. "Social Capital in the Creation of Human Capital." American Journal of Sociology 94:S95-120. https://doi .org/10.1086/228943.

Cowan, Sarah. 2014. "Secrets and Misperceptions: The Creation of Self-Fulfilling Illusions." Sociological Science 1:466-92. https ://doi.org/10.15195/v1 .a26.

Cowan, Sarah, and Delia Baldassarri. 2018. "“It Could Turn Ugly': Selective Disclosure of Attitudes in Political Discussion Networks." Social Networks 52:1-17. https://doi .org/ 10.1016/j. socnet.2017.04.002. 
Dickerson, Mechele. 2014. Homeownership and America's Financial Underclass: Flawed Premises, Broken Promises, New Prescriptions. New York, NY: Cambridge University Press. https : //doi .org/10.1017/CB09781139839280.

DiMaggio, Paul, and Hugh Louch. 1998. "Socially Embedded Consumer Transactions: For What Kinds of Purchases Do People Most Often Use Network?" American Sociological Review 63:619-37. https://doi .org/10.2307/2657331.

Drew, Rachel Bogardus, and Christopher E. Herbert. 2013. "Postrecession Drivers of Preferences for Homeownership." Housing Policy Debate 23:666-87. https://doi .org/10 . 1080/10511482.2013.823880.

Fowler, James H., and Nicholas A. Christakis. 2008. "Dynamic Spread of Happiness in a Large Social Network: Longitudinal Analysis Over 20 Years in the Framingham Heart Study." BMJ 337:a2338. https://doi .org/10.1136/bmj .a2338.

Fowler, Katherine A., R. Matthew Gladden, Kevin J. Vagi, Jamar Barnes, and Leroy Frazier. 2015. "Increase in Suicides Associated with Home Eviction and Foreclosure During the US Housing Crisis: Findings From 16 National Violent Death Reporting System States, 2005-2010." American Journal of Public Health 105:311-6. https://doi.org/10.2105/ A JPH. 2014.301945.

Gabriel, Stuart, and Gary Painter. 2003. "Pathways to Homeownership: An Analysis of the Residential Location and Homeownership Choices of Black Households in Los Angeles." The Journal of Real Estate Finance and Economics 27:87-109. https ://doi .org/10.1023/A: 1023611513835.

Gaumer, Elyzabeth, Ahuva Jacobowitz, and Jeanne Brooks-Gunn. 2014. “Building Ties: The Social Networks of Affordable-Housing Residents." Cityscape 16:47-68.

Guiso, Luigi, Paola Sapienza, and Luigi Zingales. 2013. "The Determinants of Attitudes toward Strategic Default on Mortgages." The Journal of Finance 68:1473-515. https: //doi.org/10.1111/jofi.12044.

Hilber, Christian A. L., and Yingchun Liu. 2008. "Explaining the Black-White Homeownership Gap: The Role of Own Wealth, Parental Externalities and Locational Preferences." Journal of Housing Economics 17:152-74. https://doi .org/10.1016/j . jhe .2008.02.001.

Holme, Jennifer Jellison. 2002. “Buying Homes, Buying Schools: School Choice and the Social Construction of School Quality." Harvard Educational Review 72:177-206. https : //doi.org/10.17763/haer.72.2.u6272x676823788r.

Houle, Jason N., and Danya E. Keene. 2015. “Getting Sick and Falling Behind: Health and the Risk of Mortgage Default and Home Foreclosure." Journal of Epidemiology and Community Health 69:382-7. https: //doi .org/10.1136/jech-2014-204637.

Houle, Jason N., and Michael T. Light. 2014. “The Home Foreclosure Crisis and Rising Suicide Rates, 2005 to 2010." American Journal of Public Health 104:1073-9. https : //doi . org/10.2105/AJPH. 2013.301774.

Huckfeldt, R. Robert, and John Sprague. 1995. Citizens, Politics and Social Communication: Information and Influence in an Election Campaign. New York, NY: Cambridge University Press. https://doi.org/10.1017/CB09780511664113.

Keene, Danya E., Sarah K. Cowan, and Amy Castro Baker. 2015. “'When You're in a Crisis Like That, You Don't Want People to Know': Mortgage Strain, Stigma, and Mental Health." American Journal of Public Health 105:1008-12. https ://doi .org/10. 2105/AJPH. 2014.302400.

Kleit, Rachel Garshick, and Martha Galvez. 2011. “The Location Choices of Public Housing Residents Displaced by Redevelopment: Market Constraints, Personal Preferences, or 
Social Information?" Journal of Urban Affairs 33:375-407. https : //doi . org/10.1111/j . 1467-9906.2011.00557 . x.

Krysan, Maria, and Kyle Crowder. 2017. Cycles of Segregation: Social Processes and Residential Stratification. New York, NY: Russell Sage Foundation. https://doi.org/10.7758/ 9781610448697.

Lareau, Annette, and Kimberly Goyette. 2014. Choosing Homes, Choosing Schools. New York, NY: Russell Sage Foundation.

Latané, Bibb. 1981. “The Psychology of Social Impact." American Psychologist 36:343-56. https://doi.org/10.1037/0003-066X.36.4.343.

Manturuk, Kim R., Mark R. Lindblad, and Roberto G. Quercia. 2017. A Place Called Home: The Social Dimensions of Homeownership. New York, NY: Oxford University Press.

McCabe, Brian J. 2016. No Place Like Home: Wealth, Community and the Politics of Homeownership. New York, NY: Oxford University Press. https://doi.org/10.1093/acprof : oso/9780190270452.001.0001.

McCabe, Brian J. 2018. "Why Buy a Home? Race, Ethnicity, and Homeownership Preferences in the United States." Sociology of Race and Ethnicity, http://journals. sagepub.com/ doi/10.1177/2332649217753648.

McPherson, Miller, Lynn Smith-Lovin, and James M. Cook. 2001. “Birds of a Feather: Homophily in Social Networks." Annual Review of Sociology 27:415-44. https://doi . org/10.1146/annurev.soc.27.1.415.

Nettleton, Sarah, and Roger Burrows. 2000. “When a Capital Investment Becomes an Emotional Loss: The Health Consequences of the Experience of Mortgage Possession in England." Housing Studies 15:463-78. https://doi .org/10.1080/02673030050009285.

Osypuk, Theresa L., Cleopatra Howard Caldwell, Robert W. Platt, and Dawn P. Misra. 2012. "The Consequences of Foreclosure for Depressive Symptomatology." Annals of Epidemiology 22:379-87. https://doi .org/10.1016/j . annepidem.2012.04.012.

Owens, Ann, and Susan Clampet-Lundquist. 2016. "Housing Mobility and the Intergenerational Durability of Neighborhood Poverty." Journal of Urban Affairs 39:400-20. https://doi.org/10.1080/07352166.2016.1245083.

Owens, Lindsay A. 2014. "Intrinsically Advantageous? Reexamining the Production of Class Advantage in the Case of Home Mortgage Modification." Social Forces 93:1185-209. https://doi.org/10.1093/sf/sou087.

Painter, Gary, Stuart Gabriel, and Dowell Myers. 2001. “Race, Immigrant Status, and Housing Tenure Choice." Journal of Urban Economics 49:150-67. https ://doi .org/10.1006/juec . 2000.2188 .

Pattillo, Mary. 2013. "Housing: Commodity versus Right." Annual Review of Sociology 39:509-31. https://doi.org/10.1146/annurev-soc-071312-145611.

Pew Research Center. 2011. “Home Sweet Home. Still." Pew Research Center. http: //www . pewsocialtrends .org/2011/04/12/home-sweet-home-still/.

Pribesh, Shana, and Douglas B. Downey. 1999. "Why Are Residential and School Moves Associated with Poor School Performance?" Demography 36:521-34. https ://doi .org/ $10.2307 / 2648088$.

Sacerdote, Bruce. 2001. "Peer Effects with Random Assignment: Results for Dartmouth Roommates." The Quarterly Journal of Economics 16:681-704. https: //doi .org/10.1162/ 00335530151144131. 
Seiler, Michael J., Vicky L. Seiler, Mark A. Lane, and David M. Harrison. 2012. “Fear, Shame and Guilt: Economic and Behavioral Motivations for Strategic Default." Real Estate Economics 40:S199-233. https://doi.org/10.1111/j.1540-6229.2012.00349.x.

Sharkey, Patrick. 2013. Stuck in Place: Urban Neighborhoods and the End of Progress Toward Racial Equality. Chicago, IL: University of Chicago Press. https://doi.org/10.7208/ chicago/9780226924267.001.0001.

Small, Mario Luis. 2009. Unanticipated Gains: Origins of Network Inequality in Everyday Life. New York, NY: Oxford University Press. https : //doi .org/10.1093/acprof : oso/ 9780195384352.001 .0001$.

Tach, Laura. 2014. “Diversity, Inequality, and Microsegregation: Dynamics of Inclusion and Exclusion in a Racially and Economically Diverse Community." Cityscape 16:13-45.

Weininger, Elliot, and Annette Lareau. 2014. "Sleepwalking into Neighborhoods: Social Networks and Residential Decisions." Unpublished manuscript.

White, Brent T. 2010. "Take This House and Shove It: The Emotional Drivers of Strategic Default." SMU Law Review 63:1279-329. https : //doi .org/10.2139/ssrn. 1603605.

Zavisca, Jane R., and Theodore P. Gerber. 2016. "The Socioeconomic, Demographic, and Political Effects of Housing in Comparative Perspective." Annual Review of Sociology 42:347-67. https : //doi.org/10.1146/annurev-soc-081715-074333.

Acknowledgements: An earlier version of this article was presented at the 2017 Annual Meeting of the American Sociological Association.

Brian J. McCabe: Department of Sociology, Georgetown University. E-mail: mccabeb@georgetown.edu. 